\title{
Assessment of Iron Toxicity in Lateritic Wetland Soils of Kerala and Management using Non Conventional Sources of Lime
}

\author{
Biju Joseph $^{1 *}$, R. Gladis ${ }^{1}$, B. Aparna ${ }^{1}$ and J.S. Bindhu ${ }^{2}$ \\ ${ }^{1}$ Department of Soil Science \& Agricultural Chemistry, ${ }^{2}$ Department of Agronomy, \\ College of Agriculture, Vellayani - 695522, Kerala Agricultural University, India \\ *Corresponding author
}

\section{A B S T R A C T}

\section{Keywords}

Iron toxicity, Soil acidity,

Phosphogypsum, Lime stone powder, Rice

\section{Article Info}

Accepted:

15 April 2020

Available Online:

10 May 2020
Iron toxicity and acidity are the major constraints in the laterite derived paddy soils of Kerala. More than $90 \%$ of the midland lateritic rice soils in the northern part of Kerala are strongly acidic in reaction with $\mathrm{pH}$ values in the range of 4.5 to 5.5 . The content of $0.1 \mathrm{~N}$ $\mathrm{HCl}$ extractable $\mathrm{Fe}$ in soil varied from $52.21-414.9 \mathrm{mg} \mathrm{kg}^{-1}$ and more than $50 \%$ of the rice soils showed iron toxicity problem (> $250 \mathrm{mg} \mathrm{kg}^{-1}$ of available iron). A field experiment conducted to evaluate the effectiveness of non conventional liming materials like phosphogypsum, limestone powder and their blends in managing iron toxicity and soil acidity for enhancing the yield of rice in comparison to conventional shell lime revealed that all the liming treatments significantly reduced the soil acidity and iron toxicity problem. The highest $\mathrm{pH}$ of 5.33 was recorded in the treatment receiving shell lime@600 $\mathrm{kg} / \mathrm{ha}$. The exchangeable calcium content in soil increased from $749 \mathrm{mg} \mathrm{kg}^{-1}$ in control to $909 \mathrm{mg} \mathrm{kg}^{-1}$ in phosphogypsum applied treatment. The $0.1 \mathrm{~N} \mathrm{HCl}$ extractable iron content in soil was reduced from $511 \mathrm{mg} \mathrm{kg}^{-1}$ in control to $353 \mathrm{mg} \mathrm{kg}^{-1}$ in lime stone powder 300 $\mathrm{kg} \mathrm{ha}^{-1}+$ phosphogypsum $300 \mathrm{~kg} \mathrm{ha}^{-1}$ applied treatment. The availability of nutrients were the highest in treatment receiving lime stone powder $300 \mathrm{~kg} \mathrm{ha}^{-1}+$ phosphogypsum $300 \mathrm{~kg}$ $\mathrm{ha}^{-1}$. The available $\mathrm{Mn}$ and exchangeable $\mathrm{Al}$ were found to decrease with the application of liming materials. The highest grain yield of rice $\left(5.73 \mathrm{t} \mathrm{ha}^{-1}\right)$ was obtained in the combined application of lime stone powder $300 \mathrm{~kg} \mathrm{ha}^{-1}+$ phosphogypsum $300 \mathrm{~kg} \mathrm{ha}^{-1}$.

\section{Introduction}

Rice is one of the important food grain crops cultivated in midlands of Kerala and in recent years rice production is declining due to many reasons. Among them soil acidity and toxicity of iron are the major constraints in the laterite derived mid land paddy soils. Iron toxicity is well recognized as the most widely distributed nutritional disorder in lowland rice production (Dobermann and Fairhurst, 2000). In acid soils, iron toxicity is one of the important constraints to rice production (Neue et al., 1998). The $\mathrm{H}^{+}$ion associated with soil acidity has indirect effects on mineral elements in low $\mathrm{pH}$ soils so that deficiencies of $\mathrm{P}, \mathrm{Ca}, \mathrm{Mg}, \mathrm{K}$, and $\mathrm{Zn}$ and toxicities of $\mathrm{Fe}$, $\mathrm{Al}$ and Mn commonly appear (Clark et al., 
1999). A common treatment to reduce the solubility of $\mathrm{Al}, \mathrm{Fe}$ and other metals in soil is to increase the soil $\mathrm{pH}$. Acidity and $\mathrm{Fe}$ toxicity in surface soil can be ameliorated through liming (Barber and Adams, 1984). The bulk of agricultural lime comes from ground limestone, and can be calcite $\left(\mathrm{CaCO}_{3}\right)$, dolomite $\left(\mathrm{CaCO}_{3}, \mathrm{MgCO}_{3}\right)$, or a mixture of the two. Other materials used to neutralize soil acidity, including marl, slag from iron and steel making, flue dust from cement plants, and refuse from sugar beet factories, paper mills, calcium carbide plants, rock wool plants, and water softening plants (Thomas and Hargrove, 1984).

The midland rice fields of Kerala mainly constitute the drainage basins of hills and hillocks which usually accumulates all the leachate washed down from the hills. The soils being lateritic in nature the extent of reduced forms of iron accumulating in these soils are high and toxicity of iron is a major constraint which create soil stress in laterite derived wet land paddy soils and high yielding rice varieties perform to a level of only $50 \%$ of their potential yield. Iron toxicity symptoms in rice is seen as bronzing, when $\mathrm{Fe}^{2+}$ concentration in soil solution is $250-500$ $\mathrm{mg} \mathrm{kg}^{-1}$ due to reduced conditions under prolonged submergence (Sarkar, 2013). Liming the soil before planting is the recommendation given in such situations. It is found that even high rates of lime @ 600 $\mathrm{kg} / \mathrm{ha}$ is not sufficient to contain iron toxicity and to get sustained high yields in the region. Plants suffer from acute nutritional deficiencies induced by the hostile soil $\mathrm{pH}$ and high $\mathrm{Fe}^{2+}$ ions. The cost of conventionally used shell lime is high and inhibitive and so farmers limit the use of lime to bare minimum quantities, much lower to the recommended doses. The use of non conventional liming materials is beneficial because of low cost and effectiveness in reclaiming soil acidity and iron toxicity. Hence the present investigation was carried out to study the extent of iron toxicity and acidity in rice soils of northern Kerala, to delineate the locations with toxic concentrations of $\mathrm{HCl}$ extractable iron and to evaluate the effectiveness and suitability of nonconventional calcium sources like limestone powder and phosphogypsum along with conventionally used shell lime in these soils with respect to availability of nutrients and yield of rice..

\section{Materials and Methods}

The midland rice fields selected for the study is situated in the northern part of Kerala which lies between $12^{\circ} 06^{\prime} 41^{\prime \prime}$ and $12^{\circ} 41^{\prime}$ 32 " N latitude and $74^{\circ} 59$ ' $31^{\prime \prime}$ and $75^{\circ} 15^{\prime}$ 59 " E longitude and the average elevation is 50 to $300 \mathrm{~m}$ above mean sea level. Surface (0$20 \mathrm{~cm}$ ) soil samples (3500 numbers) were collected from selected rice fields to assess the extent of soil acidity and iron toxicity in soil.

Soil $\mathrm{pH}$ was determined in 1:2.5 (soil : water) suspension using $\mathrm{pH}$ meter and the extent of acidity was classified based on the range values given in KAU (2011). The available Fe in soils were extracted with $0.1 \mathrm{~N} \mathrm{HCl}$ extract and the quantity was determined using AAS as given by Sims and Johnson (1991). Iron toxicity problem in the study area was interpreted based on the critical level given in KAU (2011).

A field experiment was carried out in farmers filed at Karivellur which is geographically located at $12.2^{\circ} \mathrm{N}$ latitude, $75.1^{\circ} \mathrm{E}$ longitude and at an altitude of $106 \mathrm{~m}$ above mean sea level, having a humid tropical climate. The experimental soil was sandy loam belonging to the taxonomical order Inceptisol, having $\mathrm{pH}$ 4.7, EC 0.12 dSm-1, CEC $7.25 \mathrm{c} \mathrm{mol} \mathrm{(p+)}$ $\mathrm{kg}-1$, organic carbon $0.33 \%$, available nitrogen $220.8 \mathrm{~kg}$ ha-1, available P2O5 61.6 $\mathrm{kg}$ ha-1, available K2O $58.56 \mathrm{~kg}$ ha-1, 
available Ca $561.75 \mathrm{mg} \mathrm{kg}^{-1}$, available $\mathrm{Mg}$ $45.7 \mathrm{mg} \mathrm{kg}^{-1}$, available $\mathrm{S} 13.25 \mathrm{mg} \mathrm{kg}^{-1}$, available $\mathrm{Fe} 544.2 \mathrm{mg} \mathrm{kg}^{-1}$, available $\mathrm{Mn}$ $32.85 \mathrm{mg} \mathrm{kg}^{-1}$, available $\mathrm{Cu} 1.26 \mathrm{mg} \mathrm{kg}^{-1}$,

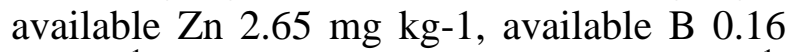
$\mathrm{mg} \mathrm{kg}^{-1}$ and exchangeable Al $135.5 \mathrm{mg} \mathrm{kg}^{-1}$. The experiment was laid out in randomized block design with four replications using rice variety Athira as test crop. There were 5 treatments viz. T1- Control (No Amendments), T2- Shell Lime (Calcium oxide) $600 \mathrm{Kg} / \mathrm{ha}, \mathrm{T} 3$ - Limestone powder (Calcium carbonate) $600 \mathrm{~kg} \mathrm{/} \mathrm{ha,} \mathrm{T4} \mathrm{-}$ Phosphogypsum (Calcium sulphate) $600 \mathrm{~kg} /$ ha and T 5 - Limestone powder $300 \mathrm{~kg} / \mathrm{ha}+$ Phosphogypsum $300 \mathrm{~kg} \mathrm{/} \mathrm{ha.} \mathrm{The}$ phosphogypsum used in the study was obtained from FACT Udyogamandal while limestone powder and shell lime were procured locally. $\mathrm{N}, \mathrm{P}$ and $\mathrm{K}$ fertilizers were applied as per package of practices recommendations (POP) of KAU (2011). Soil samples collected at harvest stage from each treatment were analyzed for available nutrients like nitrogen by alkaline permanganate method, phosphorus by bray extraction followed by colorimetric method, potassium by flame photometer, and $\mathrm{Ca}, \mathrm{Mg}$, $\mathrm{Fe}, \mathrm{Mn}, \mathrm{Cu}, \mathrm{Zn}$ and $\mathrm{Al}$ by atomic absorptions spectrophotometer method. B and $\mathrm{S}$ were analysed by photo colorimetric method. The biometric observations viz., plant height, number of productive tillers plant-1, thousand grain weight, grain and straw yield were recorded. The results obtained were statistically analyzed using statistical analysis software (SAS).

\section{Results and Discussion}

\section{Soil acidity}

The $\mathrm{pH}$ values of rice soils are given in Table 1, which varied from 4.21 to 7.44 indicating that the soils are very strongly acidic to neutral in reaction except Padana soils where $\mathrm{pH}$ was 6.17 to 9.56 (neutral to alkaline reaction). More than $90 \%$ of soils are strongly acidic and the reasons for the low $\mathrm{pH}$ is that the rice soils are lateritic and derived from acidic parent material. The dominance of Fe, $\mathrm{Mn}$ and $\mathrm{Al}$ in these soils also contribute to soil acidity due to the hydrolysis of these ions in exchange sites of soil complexes. Similar results were also reported by Jena (2013). The higher $\mathrm{pH}$ in Padana soils is attributed to the high amount of alkaline earth minerals and intrusion of sea water into rice fields as also reported by Balpande et al., (2007).

\section{Iron toxicity}

The content of $0.1 \mathrm{~N} \mathrm{HCl}$ extractable $\mathrm{Fe}$ in soil varied from $52.21-414.9 \mathrm{mg} \mathrm{kg}^{-1}$ (Table 2). More than $50 \%$ of the locations recorded iron toxicity problem. Nileswaram recorded maximum iron toxicity where $82 \%$ of samples were found to have toxic concentration of iron. The concentration of $\mathrm{Fe}^{2+}$ increases due to the reason that the midland rice fields of the study area constitute the drainage basins of hills and hillocks, which accumulates all the leachates washed down from hills and the soils being lateritic with high in iron content, the extent of reduced forms of iron accumulating is also high as reported by Jena (2013) in acid soils.

\section{Effect of liming on soil pH}

All the liming treatments significantly increased the $\mathrm{pH}$ of the soil compared to control (T1). The highest $\mathrm{pH}$ of 5.33 was recorded in T2 (Shell Lime@600 Kg / ha) which was found to be on par with treatments T3, T4 and T5 which might be attributed to the neutralising effect of these liming materials. The effect of phosphogypsum was less pronounced in comparison to other sources which may be due to the fact that phosphogypsum contains slight amounts of phosphoric acid as reported by Jena (2013) (Fig. 1). 


\section{Availability of nutrients in soil}

Application of different liming treatments significantly increased the availability of nitrogen, phosphorus and potassium in soil. The highest available $\mathrm{N}$ of $295.8 \mathrm{~kg} \mathrm{ha}^{-1}$ and available $\mathrm{K}$ of $106.8 \mathrm{~kg} \mathrm{ha}^{-1}$ were recorded in limestone powder $300 \mathrm{~kg} \mathrm{/} \mathrm{ha} \mathrm{+}$ Phosphogypsum $300 \mathrm{~kg} / \mathrm{ha}$ (T5) applied treatment, whereas the highest available $\mathrm{P}$ of $97.35 \mathrm{~kg} \mathrm{ha}^{-1}$ was observed in shell lime 600 $\mathrm{kg} / \mathrm{ha}$ (T2) applied treatment however these were found to be on par with other liming treatments. In spite of the enhanced removal of $\mathrm{N}$ for increased dry matter production, there was an increase in alkaline $\mathrm{KMnO}_{4}-\mathrm{N}$ content of the soil in the case of application of different liming material which may be due to their positive effect on $\mathrm{N}$ availability since in the present study, appreciable increase in $\mathrm{pH}$ of soil was also evidenced in these treatments. The available $\mathrm{P}$ in the soil was maximum in the treatment $\mathrm{T} 2 \quad(97.35 \quad \mathrm{~kg}$ $\left.\mathrm{ha}^{-1}\right)$ followed by T5 (91.57 $\left.\mathrm{kg} \mathrm{ha}^{-1}\right)$ and T4 $\left(87.32 \mathrm{~kg} \mathrm{ha}^{-1}\right)$. The increased available $\mathrm{P}$ content in soil might be due to the fact that the anions can replace the phosphate anion $\left[\mathrm{HPO}_{4}\right]^{2-}$ from aluminum and iron phosphates there by increasing the solubility of phosphorus. The increased availability of $\mathrm{K}$ in soil is attributed to the production of hydrogen ions during reduction of $\mathrm{Fe}$ and $\mathrm{Al}$ which would have helped in the release of $\mathrm{K}$ from the exchange sites or from the fixed pool to the soil solution. Similar results were reported by Patrick and Mikkelsen (1971).

The exchangeable calcium in the soil was significantly increased in all the treatments in comparison to control and it ranged from 749 (T1) to $909 \mathrm{ppm}$ (T4). Among the amendments, the effect of phosphogypsum was more pronounced which may be due to its better solubility in comparison to other liming materials as reported by Jena (2013). The available $\mathrm{Mg}$ (58.2 ppm) and $\mathrm{S}$ (31.65 ppm) in soil were found to be the highest in treatment T5 (Limestone powder $300 \mathrm{~kg} / \mathrm{ha}+$ Phosphogypsum $300 \mathrm{~kg} / \mathrm{ha}$ ). The increased availability of magnesium may be attributed to the increased $\mathrm{pH}$ of soil due to the addition of liming materials. The higher available sulphur in soil might be attributed to phosphogypsum which contains sulphate.

All the liming sources tried were able to significantly reduce the available iron concentration in soil from $511 \mathrm{ppm}$ (T1) to $353 \mathrm{ppm}$ (T5). The combined application of Limestone powder $300 \mathrm{~kg} / \mathrm{ha}+$ Phosphogypsum $300 \mathrm{~kg} / \mathrm{ha}$ was more effective in reducing iron toxicity which may be due to their effects in decreasing surface and sub soil acidity and increasing exchangeable calcium in soil respectively. However its performance was on par with the other sources. The available Mn content in soil was significantly decreased from 32.85 ppm in T1(control) to $25.6 \mathrm{ppm}$ in $\mathrm{T} 2$ (Shell Lime $600 \mathrm{Kg} / \mathrm{ha}$ ). Similarly exchangeable aluminum was decreased from 204 ppm in T1 to $148 \mathrm{ppm}$ in $\mathrm{T} 2$ which might be due to the reduction in soil acidity in these treatments. Availability of $\mathrm{Zn}, \mathrm{B}$ and $\mathrm{Cu}$ were not significantly influenced by the treatments, however combined application of lime stone powder + phosphogypsum gave the highest values for available $\mathrm{Zn}, \mathrm{B}$ and $\mathrm{Cu}$ showing a positive influence of liming materials on their availability (Table 3 and 4).

\section{Growth and yield of rice}

Application of different liming sources accomplished significant variation in plant growth parameters like plant height, number of tillers plant ${ }^{-1}$ and productive tillers plant ${ }^{-1}$. The treatment receiving Phosphogypsum 600 $\mathrm{kg} / \mathrm{ha}$ was superior but was found to be on par with the treatments Limestone powder $300 \mathrm{~kg} / \mathrm{ha}+$ Phosphogypsum $300 \mathrm{~kg} / \mathrm{ha}$ and Shell Lime $600 \mathrm{~kg} / \mathrm{ha}$. This can be attributed 
to the significant increase in soil $\mathrm{pH}$ in these treatments and also positive influence on the availability and uptake of macro and micro nutrients except Fe and Mn. Similar reports were made by Padmaja and Verghese (1972).

Table.1 Soil pH and extent of soil acidity in rice soils

\begin{tabular}{|c|c|c|c|c|c|c|c|}
\hline \multirow{2}{*}{$\begin{array}{l}\text { Rice Soils } \\
\text { Locations }\end{array}$} & \multicolumn{2}{|c|}{ Soil pH } & \multicolumn{5}{|c|}{ Extent of soil acidity (\%) } \\
\hline & Range & Mean & $\begin{array}{l}\text { Extreme } \\
\text { acid } \\
3.5-4.4\end{array}$ & $\begin{array}{c}\text { Very } \\
\text { strong } \\
\text { acid } \\
4.5-5.0\end{array}$ & $\begin{array}{c}\text { Strong } \\
\text { acid } \\
5.1-5.5\end{array}$ & $\begin{array}{c}\text { Moderate } \\
\text { acid } \\
5.6-6.0\end{array}$ & $\begin{array}{c}\text { Slight } \\
\text { acid } \\
6.1-6.5\end{array}$ \\
\hline Pilicode & $4.21-6.14$ & 5.32 & 8 & 22 & 31 & 28 & 11 \\
\hline Cheruvathur & $4.37-5.92$ & 5.43 & 9 & 26 & 47 & 18 & Nil \\
\hline Padana & $6.17-9.56$ & 7.91 & Nil & Nil & Nil & Nil & 4 \\
\hline Trikaripur & $4.53-6.28$ & 5.54 & Nil & 18 & 25 & 41 & 16 \\
\hline Kodombelur & $4.93-6.58$ & 5.82 & Nil & 8 & 44 & 37 & 7 \\
\hline Kinanur & $4.75-5.33$ & 5.17 & Nil & 62 & 38 & Nil & Nil \\
\hline Kanhangad & $4.57-7.44$ & 6.13 & Nil & 9 & 29 & 31 & 10 \\
\hline $\begin{array}{l}\text { Kayyur } \\
\text { Chemeni }\end{array}$ & $4.59-5.75$ & 5.21 & Nil & 55 & 28 & 17 & Nil \\
\hline Chemnad & $5.16-5.31$ & 5.26 & Nil & Nil & 100 & Nil & Nil \\
\hline Uduma & $5.43-5.81$ & 5.69 & Nil & Nil & 53 & 47 & Nil \\
\hline Pallikara & $4.63-5.64$ & 5.25 & Nil & 12 & 80 & 8 & Nil \\
\hline Pullur Periya & $4.28-5.75$ & 5.28 & Nil & 76 & 19 & 5 & Nil \\
\hline Puthige & $4.91-5.45$ & 5.24 & Nil & 28 & 72 & Nil & Nil \\
\hline Kuttikol & $4.88-5.55$ & 5.30 & Nil & 17 & 83 & Nil & Nil \\
\hline Meencha & $5.76-6.17$ & 6.01 & Nil & Nil & Nil & 89 & 11 \\
\hline Kumbla & $5.36-6.12$ & 5.88 & Nil & Nil & 32 & 58 & 10 \\
\hline Enmakaje & $4.55-5.67$ & 5.23 & Nil & 21 & 79 & Nil & Nil \\
\hline Nileswar & $3.76-5.36$ & 4.67 & 22 & 55 & 23 & Nil & Nil \\
\hline Kasargode & $4.97-5.02$ & 5.00 & Nil & 95 & 5 & Nil & Nil \\
\hline Chengala & $4.45-5.48$ & 5.04 & Nil & 88 & 12 & Nil & Nil \\
\hline Manjeswar & 5.94-7.08 & 6.63 & Nil & Nil & Nil & 15 & 61 \\
\hline Vorkadi & $5.57-6.84$ & 6.37 & Nil & Nil & Nil & 18 & 58 \\
\hline Mangalpady & $4.71-6.31$ & 5.56 & Nil & 12 & 25 & 29 & 34 \\
\hline Panathady & $6.07-6.41$ & 6.19 & Nil & Nil & Nil & Nil & 100 \\
\hline Kallar & $5.93-6.30$ & 6.03 & Nil & Nil & Nil & 36 & 64 \\
\hline Karadukka & $4.93-5.76$ & 5.41 & Nil & 28 & 56 & 16 & Nil \\
\hline Muliyar & $5.01-5.75$ & 5.31 & Nil & Nil & 86 & 14 & Nil \\
\hline Paivaligai & $5.5-6.85$ & 6.33 & Nil & Nil & Nil & 18 & 58 \\
\hline Belur & $5.18-6.55$ & 5.72 & Nil & Nil & 8 & 71 & 21 \\
\hline Kumbadaje & $5.43-6.95$ & 5.66 & Nil & Nil & 22 & 18 & 31 \\
\hline
\end{tabular}


Table. 2 Content of available iron and extent of iron toxicity in rice soils

\begin{tabular}{|c|c|c|c|c|}
\hline \multirow[t]{2}{*}{$\begin{array}{l}\text { SI } \\
\text { No }\end{array}$} & \multirow[t]{2}{*}{$\begin{array}{l}\text { Rice Soils } \\
\text { Locations }\end{array}$} & \multicolumn{2}{|c|}{$\begin{array}{c}\text { 0.1 N HCl extractable Fe content } \\
\left(\mathrm{mg} \mathrm{kg}^{-1}\right)\end{array}$} & \multirow[t]{2}{*}{$\begin{array}{r}\text { Extent of iron } \\
\text { toxicity }(\%)\end{array}$} \\
\hline & & Range & Mean & \\
\hline 1 & Pilicode & $52.21-269.5$ & 221.7 & 27 \\
\hline 2 & Cheruvathur & $173.6-349.4$ & 275.4 & 38 \\
\hline 3 & Padana & $112.6-240.7$ & 216.9 & 22 \\
\hline 4 & Trikaripur & $59.63-114.8$ & 87.1 & Nil \\
\hline 5 & Kodombelur & $83.62-234.5$ & 209.6 & 23 \\
\hline 6 & $\begin{array}{l}\text { Kinanur } \\
\text { Karimthalam }\end{array}$ & $73.09-188.3$ & 152.4 & Nil \\
\hline 7 & Kanhangad & $57.7-288.5$ & 217.2 & 14 \\
\hline 8 & Kayyur Chemeni & $112.4-303.2$ & 273.4 & 38 \\
\hline 9 & Chemnad & $188.5-382.4$ & 327.5 & 72 \\
\hline 10 & Uduma & $152.8-188.5$ & 169.8 & Nil \\
\hline 11 & Pallikara & $153.5-299.3$ & 237.4 & 59 \\
\hline 12 & Pullur Periya & $142.85-225.8$ & 200.6 & 12 \\
\hline 13 & Puthige & $127.1-302.6$ & 267.1 & 65 \\
\hline 14 & Kuttikol & $162.5-307.6$ & 230.8 & 61 \\
\hline 15 & Meencha & $66.33-132.8$ & 74.3 & Nil \\
\hline 16 & Kumbla & $147.4-270.2$ & 176.2 & 28 \\
\hline 17 & Enmakaje & $97.71-180.3$ & 131.8 & Nil \\
\hline 18 & Nileswar & $186.9-414.9$ & 383.6 & 82 \\
\hline 19 & Kasargode & $58.52-74.12$ & 69.3 & Nil \\
\hline 20 & Chengala & $80.76-146.1$ & 102.4 & Nil \\
\hline 21 & Manjeswar & $88.26-198.4$ & 132.7 & Nil \\
\hline 22 & Vorkadi & $123.1-209.5$ & 142.8 & 8 \\
\hline 23 & Mangalpady & $66.25-135.28$ & 118.7 & Nil \\
\hline 24 & Panathady & $118.2-190.6$ & 149.6 & Nil \\
\hline 25 & Kallar & $149.45-308.1$ & 223.8 & 56 \\
\hline 26 & Karadukka & $138.5-183.6$ & 151.2 & 46 \\
\hline 27 & Muliyar & $82.01-175.2$ & 102.7 & Nil \\
\hline 28 & Paivaligai & $76.6-119.38$ & 113.0 & Nil \\
\hline 29 & Belur & $86.65-135.6$ & 102.8 & Nil \\
\hline 30 & Kumbadaje & $57.36-80.66$ & 49.3 & Nil \\
\hline
\end{tabular}


Table.3 Effect of treatments on availability of major and secondary nutrients in soil

\begin{tabular}{|l|c|c|c|c|c|c|}
\hline Treatment & $\begin{array}{c}\text { Av. N } \\
\left(\mathbf{k g ~ h a}^{-1} \mathbf{)}\right.\end{array}$ & $\begin{array}{c}\text { Av.P } \\
\left(\mathbf{k g ~ h a}^{-1} \mathbf{)}\right.\end{array}$ & $\begin{array}{c}\text { Av.K } \\
\left(\mathbf{k g ~ h a}^{-\mathbf{1}} \mathbf{)}\right.\end{array}$ & $\begin{array}{c}\text { Av.Ca } \\
(\mathbf{p p m})\end{array}$ & $\begin{array}{c}\text { Av.Mg } \\
(\mathbf{p p m})\end{array}$ & $\begin{array}{c}\text { Av.S } \\
(\mathbf{p p m})\end{array}$ \\
\hline $\begin{array}{l}\text { T1. Control - } \\
\text { No Amendments }\end{array}$ & 241.5 & 72.60 & 64.5 & 749 & 47.30 & 21.12 \\
\hline $\begin{array}{l}\text { T2. Shell Lime 600 Kg / } \\
\text { ha }\end{array}$ & 290.2 & 97.35 & 97.4 & 894 & 54.41 & 30.41 \\
\hline $\begin{array}{l}\text { T3.Limestone powder 600 } \\
\text { Kg / ha }\end{array}$ & 287.3 & 81.00 & 91.7 & 871 & 52.58 & 30.08 \\
\hline $\begin{array}{l}\text { T4. Phosphogypsum 600 } \\
\text { Kg/ha }\end{array}$ & 291.6 & 87.32 & 87.2 & 909 & 53.52 & 31.60 \\
\hline $\begin{array}{l}\text { T5. Limestone powder } \\
\text { 300 Kg / ha } \\
\text { Phosphogypsum 300 Kg / } \\
\text { ha }\end{array}$ & 295.8 & 91.57 & 106.8 & 902 & 58.20 & 31.65 \\
\hline CD (0.05) & & & & & & \\
\hline
\end{tabular}

Table.4 Effect of treatments on availability of micro nutrients in soil

\begin{tabular}{|l|l|l|c|c|c|c|}
\hline Treatment & $\begin{array}{l}\text { Av. } \\
\text { (ppm) }\end{array}$ & $\begin{array}{l}\text { Av. Mn } \\
\text { (ppm) }\end{array}$ & $\begin{array}{c}\text { Av. Zn } \\
\text { (ppm) }\end{array}$ & $\begin{array}{c}\text { Av. Cu } \\
\text { (ppm) }\end{array}$ & Av. B & $\begin{array}{l}\text { Ex.Al } \\
\text { (ppm) }\end{array}$ \\
\hline $\begin{array}{l}\text { T1. Control - Nom) } \\
\text { Amendments }\end{array}$ & 511 & 32.85 & 4.00 & 3.68 & 0.23 & 204.0 \\
\hline $\begin{array}{l}\text { T2. Shell Lime 600 } \\
\text { Kg / ha }\end{array}$ & 387 & 25.60 & 4.09 & 3.79 & 0.24 & 148.0 \\
\hline $\begin{array}{l}\text { T3.Limestone } \\
\text { powder 600 Kg / ha }\end{array}$ & 369 & 27.90 & 4.04 & 3.76 & 0.24 & 160.0 \\
\hline $\begin{array}{l}\text { T4. Phosphogypsum } \\
\text { 600 Kg / ha }\end{array}$ & 375 & 25.70 & 4.18 & 3.75 & 0.23 & 155.3 \\
\hline $\begin{array}{l}\text { T5. Limestone } \\
\text { powder 300 Kg / ha + } \\
\text { Phosphogypsum 300 }\end{array}$ & 353 & 25.76 & 4.19 & 3.79 & 0.26 & 154.6 \\
\hline Kg / ha & & & & & & \\
\hline CD (0.05) & 29.8 & 1.26 & NS & NS & NS & 35.1 \\
\hline
\end{tabular}


Table.5 Effect of treatments on growth parameters, yield attributes and yield of rice

\begin{tabular}{|c|c|c|c|c|c|c|c|}
\hline Treatment & $\begin{array}{l}\text { Plant } \\
\text { height } \\
(\mathrm{cm})\end{array}$ & $\begin{array}{l}\text { Number } \\
\text { of tillers/ } \\
\text { plant }\end{array}$ & $\begin{array}{l}\text { Productiv } \\
\text { e tillers } \\
\text { /plant }\end{array}$ & $\begin{array}{l}\text { Panicle } \\
\text { weight } \\
\text { plant }^{-1} \\
\text { (g) }\end{array}$ & $\begin{array}{l}\text { Thousan } \\
\text { d grain } \\
\text { weight } \\
\text { (g) }\end{array}$ & $\begin{array}{c}\text { Grain } \\
\text { Yield } \\
(\mathbf{t} / \text { ha })\end{array}$ & $\begin{array}{c}\text { straw } \\
\text { yield } \\
\left(\mathrm{t} \mathrm{ha}^{-1}\right)\end{array}$ \\
\hline $\begin{array}{l}\text { T1. Control } \\
\text {-No } \\
\text { Amendments }\end{array}$ & 84.33 & 16.00 & 15.66 & 37.13 & 29.43 & 4.46 & 5.85 \\
\hline $\begin{array}{l}\text { T2. Shell Lime } \\
600 \mathrm{Kg} / \mathrm{ha}\end{array}$ & 88.00 & 18.00 & 17.00 & 40.60 & 30.20 & 5.55 & 6.67 \\
\hline $\begin{array}{l}\text { T3.Limestone } \\
\text { powder } 600 \mathrm{Kg} / \\
\text { ha }\end{array}$ & 83.33 & 16.66 & 15.33 & 36.26 & 29.53 & 5.61 & 6.43 \\
\hline $\begin{array}{l}\text { T4. } \\
\text { Phosphogypsum } \\
600 \mathrm{Kg} \text { / ha }\end{array}$ & 91.00 & 19.66 & 18.33 & 44.06 & 30.60 & 5.40 & 6.64 \\
\hline $\begin{array}{l}\text { T5. Limestone } \\
\text { powder } 300 \mathrm{Kg} / \\
\text { ha } \\
\text { Phosphogypsum } \\
300 \mathrm{Kg} / \mathrm{ha}\end{array}$ & 87.33 & 18.93 & 17.00 & 38.00 & 29.76 & 5.73 & 6.92 \\
\hline CD (0.05) & 3.61 & 1.30 & 2.44 & 6.18 & 1.47 & 0.39 & 0.40 \\
\hline
\end{tabular}

Fig.1 pH of soil as influenced by various treatments 
The yield attributes (panicle weight plant $^{-1}$ and thousand grain weight), grain and straw yield of rice were significantly influenced by the application of various liming sources. Application of Phosphogypsum $600 \mathrm{~kg} /$ ha was significantly superior with respect to yield attributes which was on par with Shell Lime $600 \mathrm{~kg} / \mathrm{ha}$ and Limestone powder 300 $\mathrm{kg} / \mathrm{ha}+$ Phosphogypsum $300 \mathrm{~kg} /$ ha In the case of grain and straw yield, all the treatments resulted in significant increase over control. The treatment receiving Limestone powder $300 \mathrm{~kg} \mathrm{/} \mathrm{ha} \mathrm{+}$ Phosphogypsum $300 \mathrm{~kg} /$ ha was superior but was on par with the sources Phosphogypsum $600 \mathrm{~kg} / \mathrm{ha}$ and Shell Lime $600 \mathrm{~kg} / \mathrm{ha}$. The tune of increase in grain and straw yield in the superior treatment (Limestone powder $300 \mathrm{~kg}$ / ha + Phosphogypsum $300 \mathrm{~kg} / \mathrm{ha}$ ) was 5.73 and $6.92 \mathrm{t} \mathrm{ha}^{-1}$ respectively (Table 5). The positive trend of results for yield obtained is quite reasonable because a significant increase was noticed in these treatments for available nutrients in soil, plant growth parameter likes plant height, number of tillers plant $^{-1}$ and productive tillers plant ${ }^{-1}$, yield attributes like panicle weight plant $^{-1}$ and thousand grain weight and also the prevalence of substantial synergistic effect of treatments on availability, absorption and translocation of nutrients. Similar results have also been reported by Bridgit (1999) and Sarkar (2013).

From the study it can be concluded that laterite derived paddy soils of northern Kerala have acidity and iron toxicity problems. The results from the field experiment indicate that iron toxicity and soil acidity in laterite derived paddy soils can be managed by the combined soil application of $300 \mathrm{~kg} / \mathrm{ha}$ of limestone powder and $300 \mathrm{~kg} / \mathrm{ha}$ of phosphogypsum. The availability of nutrients in soil, uptake of nutrients by plant and the growth and yield of rice crop was increased due to the combined application of $300 \mathrm{~kg} / \mathrm{ha}$ of limestone powder and $300 \mathrm{~kg} / \mathrm{ha}$ of phosphogypsum.

\section{Acknowledgements}

The authors would like to acknowledge the Kerala Agricultural University for the technical and financial support.

\section{References}

Balpende, H.S., Challa, O. and Prasad, J. 2007. Characterization and classification of grape growing soils in Nasik district, Maharastra. J. Indian soc. soil sci., 55: 80-83.

Barber, S. A. and Adams, F. (1984). Liming materials and practices. Agronomy (EUA).

Bridgit, T.K. 1999. Nutritional balance analysis for productivity improvement of rice in iron rich laterite alluviam. Ph.D. thesis, Kerala Agricultural University, Thrissur, $302 \mathrm{pp}$.

Clark, R. B., Zobel, R. W. and Zeto, S. K. (1999). Effects of mycorrhizal fungus isolates on mineral acquisition by Panicum virgatum in acidic soil. Mycorrhiza, 9(3), 167-176.

Dobermann, A. and Fairhurst, T. (2000). Rice: Nutrient disorders \& nutrient management (1st edition ed.). Manila: Int. Rice Res. Inst.

Jena, D. 2013. Acid soils of Odisha. In: Acid soils their chemistry and management. (A.K. Sarkar, Ed.) pp. 197.

Kerala Agricultural University (KAU). 2011. Package of practices Recommendations: Crops (14th Ed.), Kerala Agricultural University, Thrissur, 360 pp.

Marschner, H. 1995. Mineral nutrition of higher plants. Academic Press, London, San Diego, 889p.

Neue, H. U., Quijano, C., Senadhira, D. and Setter, T. (1998). Strategies for dealing with micronutrient disorders and salinity in lowland rice systems. Field Crop Res, 56, 139-155.

Padmaja, P. and Verghese, E.J. 1972. Effect of Calcium and Silicon on the uptake of 
plant nutrients and quality of straw and grain of paddy. Agric. Res. J. Kerala 10(2): 100-105.

Patrick, W.H. and Mikkelsen, D.S. 1971. Plant nutrient behaviour in flooded soil. In: Olson, R. A. (ed.), Fertilizer technology and use. Soil Science Society of America, Madison, USA, pp.187-215.

Sarkar, A.K. 2013. Acid soils their chemistry and management. New India Publishing Agency. New Delhi.
Sims, J.T and Johnson, G.V. 1991. Micronutrient soil tests in agriculture. In:Mortvedt. J.J., Cose, F.R., Shuman, L.M. and Welch, R.M. (Eds.), Methods of soil analysis. Soil sci. Soc. America, Madison, USA, pp. 427-472.

Thomas, G. W. and Hargrove, W. L. (1984). The chemistry of soil acidity. In 'Soil Acidity and Liming'. (Ed. F. Adams.) pp. 3-56. Am. Soc. Agron. Crop Sci. Soc. Am./Soil Sci. Soc. Am.: Madison, Wisconsin.

\section{How to cite this article:}

Biju Joseph, R. Gladis, B. Aparna and Bindhu, J.S. 2020. Assessment of Iron Toxicity in Lateritic Wetland Soils of Kerala and Management using Non Conventional Sources of Lime. Int.J.Curr.Microbiol.App.Sci. 9(05): 2139-2148. doi: https://doi.org/10.20546/ijcmas.2020.905.244 